\title{
ENVIRONMENTAL REgime FOR DEVELOPMENT OF AN Oil and Gas Project in the Newfoundland OfFshore
}

\author{
GERLINDE VAN DRIEL, Q.C. AND \\ ALEXANDER MACDONALD, Q.C.
}

Environmental regulatory approval is an important and necessary step in the development of oil and gas projects in the Newfoundland offshore. The approval process, however, should be as efficient and definitive as possible. This article sets out how the approval process under the Accord Implementation Acts and the Canadian Environmental Assessment Act can be merged so that duplication and unnecessary delay are avoided.
L'approbation régulatrice sur l'environnement est une mesure importante et nécessaire pour le développement de projets pétroliers et gaziers dans la zone extra cötière de Terre-Neuve. Le processus d'approbation devrait cependant ètre aussi efficace et définitif que possible. Cet article démontre de quelle façon le processus d'approbation peut ètre fusionné en vertu des Lois de mise en auvre des accords et de la Loi canadienne sur l'évaluation environnementale de manière $\dot{a}$ éviter le chevauchement et les retards inutiles.

\section{TABLE OF CONTENTS}

I. INTRODUCTION

A. REgULATORY JURISDICTION - WHY

PROPONENTS MUST COMPLY WITH TWO REGIMES . . . . . . 132

B. LegisLATIVE GOAL OF STREAMLINING THE REgIMES $\ldots \ldots 132$

II. CNOPB APPROVAL PROCESS $\ldots \ldots \ldots \ldots \ldots \ldots \ldots \ldots \ldots \ldots$

A. THE REQUiRED DocUments $\ldots \ldots \ldots \ldots \ldots \ldots \ldots \ldots 134$

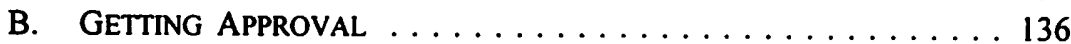

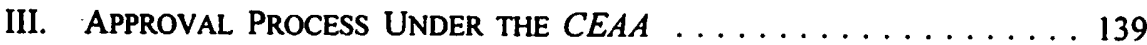

A. CONSULTATION WITH OTHER FEDERAL AUTHORITIES . . . . 140

B. STEPS IN THE COMPREHENSIVE STUDY PATH $\ldots \ldots \ldots \ldots 141$

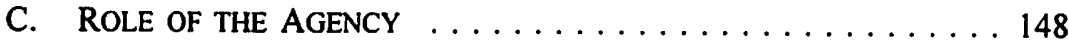

IV. PRACTICAL OVERLAP - HOW THE TWo

SYSTEMS FIT TOGETHER $\ldots \ldots \ldots \ldots \ldots \ldots \ldots \ldots \ldots \ldots$

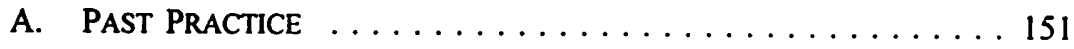

B. SUGgestions For the FUtURE $\ldots \ldots \ldots \ldots \ldots \ldots \ldots$

V. Conclusions ...................... 164

\section{INTRODUCTION}

Project owners who wish to develop an oil and gas project in the Newfoundland offshore are subject to two legislative regimes: the Accord Implementation Acts ${ }^{1}$ and the Canadian Environmental Assessment Act. ${ }^{2}$ Each of these Acts imposes separate demands

Partners with Patterson Palmer Hunt Murphy, St. John's, Newfoundland. Gratefully acknowledged is the assistance of Janet O'Reilly and Stephanie Hickman, associates at Patterson Palmer Hunt Murphy, with the preparation of this article.

The Canada-Newfoundland Atlantic Accord Implementation Newfoundland Act, R.S.N. 1990, c. C-2 [hereinafter Newfoundland Accord Implementation Act] and the Canada-Newfoundland Atlantic Accord Implementation Act, S.C. 1987, c. 3 [hereinafter Federal Accord Implementation Act], [collectively hereinafter Accord Implementation Acts]. 
and timelines upon project owners. This article will explore how the regulatory approval processes, under these pieces of legislation, interrelate.

\section{A. Regulatory JuRisdiction - Why Proponents MUST COMPLY WITH TWO REgIMES}

No work or activity may be carried out in the offshore area without obtaining an authorization from the Canada-Newfoundland Offshore Petroleum Board ("CNOPB"), ${ }^{3}$ and part of the procedure for obtaining a production operations authorization is the approval of a Development Plan by the CNOPB. ${ }^{4}$ Thus the approval of a Development Plan by the CNOPB is a necessary first step for a project owner to develop an oil and gas project in the Newfoundland offshore.

Similarly, under the $C E A A$ approval cannot be granted to proceed with the development of an oil and gas project in the Newfoundland offshore unless an environmental assessment is completed in accordance with that $A c t .{ }^{5}$ The $C E A A$ is clear that where approval is denied under the $C E A A$, the project may not proceed even if it is approved under some other act. ${ }^{6}$ Therefore, the project owner finds itself subject to two legislative regimes and two approval procedures.

\section{B. Legislative Goal OF STREamLining the Regimes}

The Accord Implementation Acts call upon the CNOPB to ensure effective coordination and to avoid duplication of work and activities by concluding memoranda of understanding with appropriate departments and agencies of both the government of Canada and the government of the province. This is especially so in relation to, among other things, environmental regulation. ${ }^{7}$

The "Guide to the Preparation of a Comprehensive Study for Proponents and Responsible Authorities" produced by the Canadian Environmental Assessment Agency makes a clear statement on the goal of streamlining the regulatory approval process:

Without close cooperation, a project might be subject to separate environmental assessments, resulting in unnecessary duplication, confusion, and excessive costs to all parties.... Harmonization also benefits private-sector decision makers carrying out [environmental assessments] by streamlining regulatory approval processes and reducing planning uncertainties and delays. ${ }^{\text {" }}$

Newfoundland Accord Implementation Act, supra note 1, s. 133; Federal Accord Implementation Act, supra note 1 , s. 137.

- Newfoundland Accord Implementation Act, ibid., s. 135; Federal Accord Implementation Act, ibid., s. 139.

Supra note 2, s. 13.

lbid., s. 37(3)(b): "[N]otwithstanding any other Act of Parliament, no power, duty or function conferred by or under that Act or any regulation made thereunder shall be exercised or performed that would permit the project to be carried out in whole or in part."

Federal Accord Implementation Act, supra note 1, s. 46.

C.E.A.A., Guide (May 1997), online: Government of Canada <www.ceaa-acee.gc.ca/0011/ 0001/0003/comps_e.htm> (date accessed: 2 January 2002) [hereinafter $C E A A$ Guide]. 
All parties involved benefit from the coordination of efforts between decision-making bodies. For proponents, the public, and decision-makers the coordination of regulatory approval processes increases efficiency and certainty of procedure.

To assess how the legislation provides for the merging of the two approval systems into one streamlined process, we first examine the process required under each system separately.

\section{CNOPB APPROVAl Process}

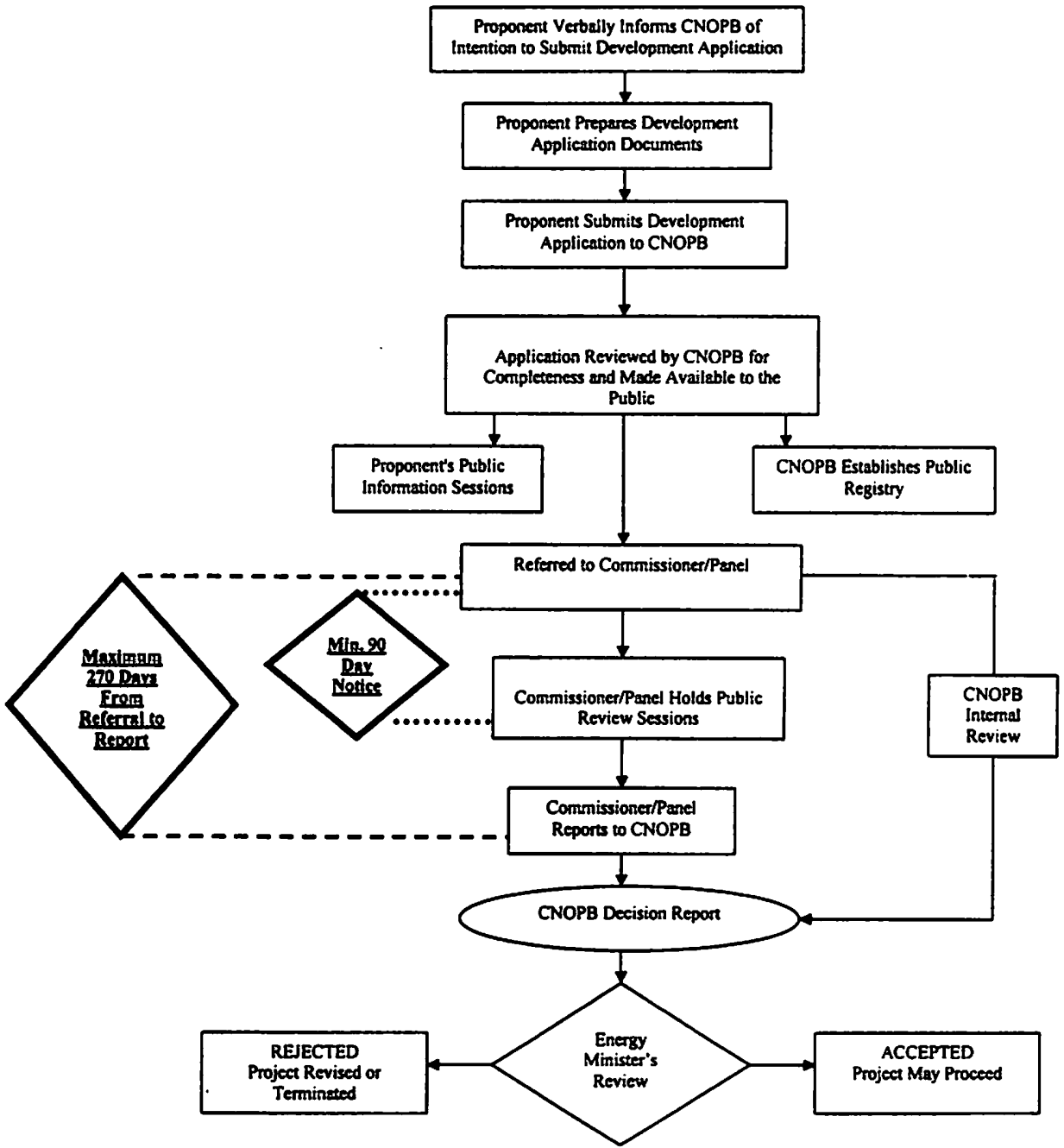




\section{A. THE REQUIRED DOCUMENTS}

The Accord Implementation Acts and the "Development Application Guidelines" provide that the proponent or applicant ("Proponent") must submit to the CNOPB:

- a development plan ("Development Plan");

- a Canada-Newfoundland benefits plan ("Benefits Plan");

- a development application summary ("Summary");

- $\quad$ an environmental impact statement ("EIS");

- a socio-economic impact statement ("SEIS");

- a safety plan ("Safety Plan"); and

- an environmental protection plan ("EPP").

Although the "CNOPB Guidelines" indicate that the Safety Plan, EIS, SEIS, and EPP are only supplied if requested, it is difficult to envision a case where they are not required. ${ }^{9}$

The Development Plan is comprised of two parts. Part I provides an overview of plans for development and a summary of all information used to prepare the plan. Part II encloses copies of the studies, reports, and proposals relied on in the preparation of the Development Plan and in the consideration of alternatives. ${ }^{10}$ The Development Plan describes:

- the general approach to developing the field;

- any alternative exploitation schemes;

- alternative production and transportation systems that were considered; and

- the rationale for selecting the proposed approach.

The Development Plan must provide sufficient information to permit a thorough public review of the project.

The Proponent must submit a Summary, that is, a general overview, which is sufficiently comprehensive to allow the reader to come to an informed opinion. The Summary includes:

- a description of the project (including environmental and economic settings);

- possible major environmental and socio-economic effects;

CNOPB, Guide "Development Application Guidelines" (December 1998), online: Government of Canada <www.cnopb.nfnet.com> (date accessed: 2 January 2002) [hereinafter CNOPB Guidelines]. While the language of the CNOPB Guidelines and the CEAA Guide is permissive, the suggestions made by these documents are, in reality, more akin to requirements. Therefore, throughout this article, the provisions of the CNOPB Guidelines and the CEAA Guide have been treated as requirements. c. 1.1, drafted under the authority of s. 147(1) of the Newfoundland Accord Implementation Act and s. 151.1 of the Federal Accord Implementation Act, which sets out the board's power to issue guidelines regarding the contents of the Development Plan. 
- $\quad$ expected level of industrial and employment opportunities for Canada and Newfoundland;

- measures that will be taken to avoid or mitigate adverse environmental and socio-economic effects;

- residual effects and their significance; and

- programs planned to monitor the accuracy of predictions and compliance with regulations."

Under the Accord Implementation Acts, approval of the Benefits Plan is a prerequisite to approval of the Development Plan. ${ }^{12}$ The CNOPB has the authority to waive this requirement. However, given the discussion of the role of the public set out below, it seems unlikely that the CNOPB would exercise this power. The Benefits Plan is of particular importance to the public as it discusses the ways in which "full and fair opportunity" will be given to Canadian and Newfoundland suppliers of goods and services to supply the needs of the project. This document must also specify the ways in which Newfoundlanders and Canadians will be provided with employment and training opportunities.

For the Safety Plan, the Proponent is asked to provide as much detail as the stage of development of the project permits. The Proponent is expected to progressively update the Safety Plan as new information becomes available or new procedures are established. The Safety Plan contains:

- the corporate safety management policy;

- the procedures that will be established to deal with occupational health and safety issues;

- a description of the training and qualifications required for each production installation;

- a contingency plan for emergency situations;

- the operational procedures regarding monitoring and forecasting conditions of the physical environment; and

- a description of the safety related provisions for facilities and equipment. ${ }^{13}$

The documents required under the CNOPB approval regime that have the most in common with the documents required under the CEAA regime are the EIS and SEIS. Generally, the EIS identifies interactions between the development project and the environment. It also sets out the anticipated effects of the project on the environment and states the policies and procedures that the Proponent intends to follow to reduce possible harmful effects. The EIS has five basic sections, which consider the proposed development, the existing environment, environmental effects, mitigation and monitoring, and residual effects. ${ }^{14}$ 
The SEIS describes the results of the Proponent's analysis of the positive and negative effects on the social and economic aspects of Newfoundland communities directly affected by the project. It deals with:

- $\quad$ project alternatives;

- $\quad$ studies of the impact on demography;

- $\quad$ public infrastructure and services;

- housing;

- municipal government;

- social services and facilities;

- the fishery;

- land and resource use;

- $\quad$ socio-cultural issues;

- the geographical scope of the project;

- the assessment methodology used; and

- the cumulative effects from other known major industrial projects. ${ }^{15}$

In the EPP, the Proponent is asked to provide as much detail as the stage of development of the project permits. The Proponent is expected to progressively update the EPP as new information becomes available or new procedures are established. The EPP should include descriptions of:

- the methods to be used to deal with environmental waste and chemicals;

- $\quad$ proposed protective and mitigative measures;

- contingency plans for emergency situations;

- monitoring programs; and

- any plans for the restoration of the site upon abandonment. ${ }^{16}$

The CNOPB Guidelines provide that the Proponent consult with the CNOPB on an ongoing basis during the preparation of documents. The CNOPB, in turn, will consult with government departments and convey their objectives to the Proponent.

\section{B. GetTing APPROVAL}

A Proponent should inform the CNOPB of its intention to submit a development application for approval. Initially this may be done verbally; however, formal written notice must also be sent to the CNOPB. ${ }^{17}$ The Proponent then submits its development application with all of the required supporting documents. ${ }^{18}$ The CNOPB does a preliminary review of the application to ensure that it is complete. The CNOPB also ensures that the Summary is distributed to the public. ${ }^{19}$

\footnotetext{
is Ibid., c. 7.0 .

"Ibid., c. 9.0 .

$17 \quad$ Ibid., c. 2.1

18 Accord Implementation Acts, supra note 1, s. 44.

19 CNOPB Guidelines, supra note 9, c. 2.3.
} 
The Proponent is required to schedule public information sessions in communities affected by the project. These sessions should be scheduled well enough in advance so that potential interveners can consider the application and respond at the sessions. ${ }^{20}$

The CNOPB then does a substantive review of the application package. This internal review is done to determine whether a public hearing is required. This review involves consultations with federal and provincial government departments, agencies, and any experts thought necessary by the CNOPB. ${ }^{21}$

While the CNOPB does have the authority to do only an internal review ${ }^{22}$ (in consultation with federal and provincial government departments), it may only do so when it is in the public interest not to hold public hearings. This circumstance seems very unlikely. The Hibernia Project and the Terra Nova Project both underwent public reviews. The White Rose public review is scheduled for the summer of 2001. All three oil developments in the Newfoundland offshore have been subject to the public review process. Therefore, it appears that the public hearing process under the CNOPB's approval procedure is unavoidable.

After the Proponent has submitted its development application documents to the CNOPB and the decision to proceed with a public review is made, the CNOPB determines the structure of the panel or appoints a commissioner. ${ }^{23}$ The panel or commissioner then publishes a notice which sets out:

- its terms of reference;

- the general purpose;

- timelines for the hearings;

- objectives of the hearings;

- instructions to interveners, including procedures for making submissions; and

- contact information for the person from whom further information can be obtained.

The panel or commissioner then reviews the development application documents referred to it by the CNOPB and any comments received from interested persons in preparation for the hearings. The powers of the panel or commissioner during the hearings are set by the Accord Implementation Acts. ${ }^{24}$ The panel or commissioner does not act as

Ibid., c. 2.2 .

Ibid., c. 2.3 .

Federal Accord Implementation Act, supra note 1, s. 44(1) - subject to a ministerial directive given under s. $\mathbf{4 2}$ of either $A c t$, which can either direct that public review must happen or that it may not happen.

The Hibernia and Terra Nova Projects' approval processes involved a panel, whereas the White Rose Project has a single commissioner.

Supra note 1; Federal Accord Implementation Act, supra note I, s. 44. The powers of the Panel are set by the federal and provincial governments, on the request of the CNOPB, and can be equivalent to the powers conferred on commissioners under the provincial Public Inquiries Act, R.S.N. 1990. P-38 or Part I of the federal Inquiries Act, R.S.C. 1985, c. I-11. 
a judicial body, but is, instead, a fact-finding body that then reports to the decisionmaking body, the CNOPB.

The participants in the hearings are usually the Proponent's representative and interveners. The panel or commissioner has the authority to require that interveners use written submissions only; however, this requirement may be waived. All written submissions provided during the hearings will be made available for public review in a facility provided by the CNOPB ${ }^{25}$ When the panel or commissioner has concluded its hearings, it then submits a report to the CNOPB, the federal Minister of Energy, Mines and Resources, and the Newfoundland and Labrador Minister of Mines and Energy ${ }^{26}$ ("Ministers"). It also submits all the evidence received by it during the hearings.

When it receives the panel's or commissioner's report ("CNOPB Hearing Report"), the CNOPB may approve Part II of the Development Plan on its own. ${ }^{27}$ Part I, however, is subject to the fundamental decision sections of the Accord Implementation Acts ${ }^{28}$ and must be approved by the provincial minister. ${ }^{29}$

Prior to approving the Development Plan, the CNOPB must approve the Benefits Plan. Once both ministers have approved the development application, ${ }^{30}$ the CNOPB's decision becomes final.

For the White Rose Project, for example, the commissioner has established a web site where submissions, press releases, and the commissioner's correspondence can be accessed by the public. Newfoundland Accord Implementation Act, supra note 1, s. 2.

Unless indicated in the Accord Implementation Acts, the CNOPB's completion of duties under the Accord Implementation Acts is not subject to review by either arm of the government: Federal Accord Implementation Act, supra note 1, s. 30.

Ibid., ss. 31-40. Being made subject to these sections, by definition (Accord Implementation Acts, s. 2) makes this approval a fundamental decision. Fundamental decisions require the approval of one of the ministers (which one, is determined by the state of self-sufficiency and security of supply, as defined in the Accord Implementation Acts).

This is so regardless of the state of self-sufficiency and security of supply, unlike other fundamental decisions. This approval will stand unless the federal minister determines that the provincial minister's approval or disapproval would unreasonably delay the attainment of self-sufficiency or security of supply. If this occurs, the federal minister may substitute his or her decision for the decision of the provincial minister, ibid., s. 34.

Or undergone the procedures set out in the Act to resolve disputes between the ministers, ibid., s. $37(1)$. 


\section{Approval Process Under CEAA}

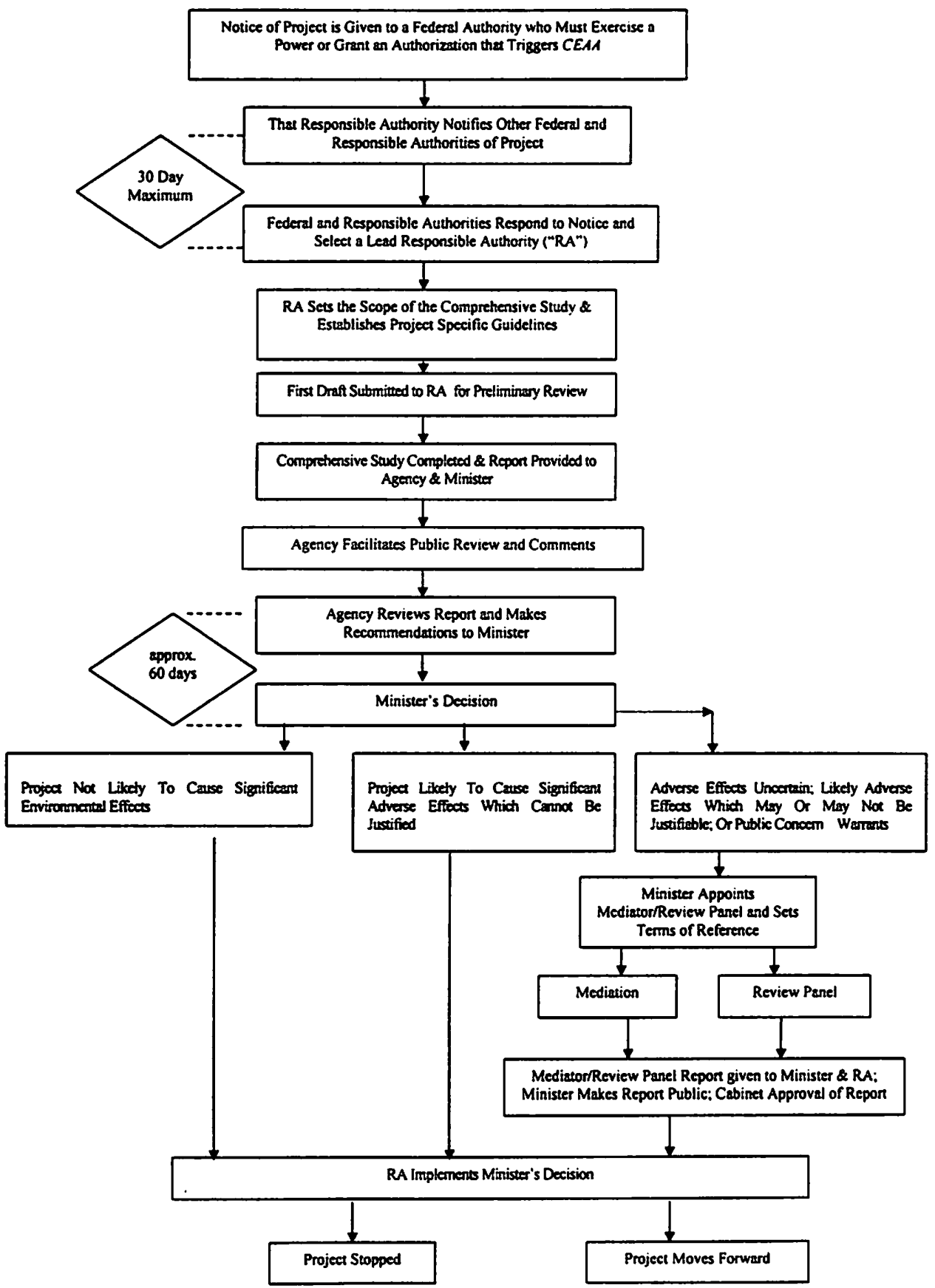




\section{A. CONSUltation With OTHER Federal Authorities}

An environmental assessment under the $C E A A$ must be carried out for all oil and gas developments, which means the preliminary determination of whether one will be required pursuant to the Regulations Respecting Coordination by Federal Authorities of Environmental Assessment Procedures and Requirements is not relevant. ${ }^{31}$ However, it is important to note that the federal authorities who are consulted pursuant to the Coordination Regulations are the federal authorities who will be consulted on a continuing basis throughout the project.

The federal authorities consulted include those who are likely to either:

- exercise a power in respect of the project; or

- be in possession of specialist or expert information or knowledge that is necessary to conduct the environmental assessment of the project. ${ }^{32}$

The authorities who would be consulted for an oil and gas development in the Newfoundland offshore include:

- the CNOPB;

- Atlantic Canada Opportunities Agency;

- Canada Customs and Revenue Agency;

- Canadian Environmental Assessment Agency;

- Canadian Transportation Accident Investigation and Safety Board;

- Canadian Transportation Agency;

- Citizenship and Immigration Canada;

- Environment Canada;

- Fisheries and Oceans Canada;

- Human Resources Development Canada;

- Industry Canada;

- National Defence;

- National Energy Board;

- Natural Resources Canada;

- Transport Canada;

- Newfoundland and Labrador Department of Mines and Energy;

- Newfoundland and Labrador Department of Environment and Labour;

- Newfoundland and Labrador Department of Fisheries and Aquaculture; and

- Work Place Health, Safety and Compensation Commission of Newfoundland and Labrador. ${ }^{33}$ 
Among the federal authorities, there are those departments or agencies that exercise powers that serve as triggers for the CEAA approval procedure. ${ }^{34}$ These federal authorities are deemed by the $C E A A$ to be responsible authorities and are charged with the responsibility of ensuring that the environmental assessment is conducted. ${ }^{35}$

If there is more than one responsible authority, they must coordinate the conduct of the environmental assessment between them. They may designate a lead responsible authority ("RA") or decide to use a team structure. ${ }^{36}$ The lead RA does not have any veto or extraordinary power over the other responsible authorities, but instead must consult with the other responsible authorities on an ongoing basis to achieve consensus. ${ }^{37}$ As well, ongoing consultation with the other responsible authorities, and other federal authorities who may have relevant expertise, is advisable as it leads to a better assessment and increases public confidence in the process. ${ }^{38}$

The $C E A A$ provides for two methods of environmental assessment: screening and comprehensive studies. Offshore oil and gas developments are listed in the Comprehensive Study List Regulations ${ }^{39}$ and must undergo a comprehensive study.

\section{B. Steps in the Comprehensive Study Path}

Generally, the steps in the comprehensive study path begin with a determination of who will act as the lead RA (in the Newfoundland offshore the RA is the CNOPB). The RA then determines the scope of the study. While the comprehensive study report ("Comprehensive Study Report") is the responsibility of the RA, this task is often delegated to the Proponent. The Proponent prepares a first draft of the Comprehensive Study Report which is reviewed by the RA. When the Proponent and the RA have finalized the draft, a copy is sent to the Canadian Environmental Assessment Agency ("Agency") for review. The Comprehensive Study Report is then officially submitted to the Agency and the Federal Minister of Environment ("Minister"). The Agency makes the Comprehensive Study Report available to the public and receives comments from them. The Minister must then decide whether the project should:

- be allowed to proceed;

- $\quad$ not be allowed to proceed; or

The CEAA, supra note 2 , s. 5(1) states that an environmental assessment is required when the Proponent is a federal authority; when a federal authority provides financial assistance to the Proponent; when the federal authority has administration of federal lands and sells, leases or otherwise disposes of these lands or any interest in those lands for the purpose of enabling the project to be carried out; and when a federal authority issues a permit for licence or grants an approval or takes any other action to enable the project to be carried out that is enumerated pursuant to s. 59(f) (i.e., included in the Law List Regulations, S.O.R./94-636).

is lbid., s. $11(1)$.

36 Ibid., s. 12(1) and according to Step 1.4 of the CEAA Guide, supra note 8 . If there is a dispute among the RAs as to how to proceed, the Agency can advise them under s. 12(2) of the Act. For the purposes of this article, the term RA is meant to refer to the lead RA. 
- be referred to a public review panel or to mediation.

If a panel or mediation is used, the panel or mediator produces a report, which is submitted to the Minister and the RA. The Minister then reviews the Comprehensive Study Report and the panel or mediator's report, if applicable, and decides if the RA should exercise its power or grant the approval that allows the project to proceed.

The RA's role begins with determining the process for the comprehensive study, setting the scope of the project and the scope of the individual factors to be considered. It is the RA's responsibility to ensure that all relevant federal authorities, other responsible authorities, and the public ${ }^{40}$ are consulted and included in the preparation of the Comprehensive Study Report. It is the RA who then submits the finalized Comprehensive Study Report to the Minister and the Agency. The RA then implements the Minister's decision." Once the project has been approved, the RA is responsible to ensure that appropriate mitigation measures and follow-up programs are implemented.

The Proponent has much to gain from an efficient environmental assessment process. The Proponent initiates the process by providing a project description to the RA. It then assists in establishing reasonable timelines for the process. The Proponent conducts the comprehensive study in conjunction with the RA, with input from other federal authorities and the public. The Proponent prepares the Comprehensive Study Report, ensuring that the concerns of the RA, the public, and federal authorities about the environmental effects receive the appropriate attention as well as ensuring that any significant technical or scientific issues have been reviewed and addressed.

\section{PREPARING FOR THE COMPREhENSIVE Study}

The RA will consult with the Proponent, federal authorities, and the Agency on the scope of the project and the factors to be considered. This leads to project-specific guidelines and sets the parameters of the Comprehensive Study Report. A successful scoping increases the efficiency of the process, which in turn reduces the chances of the need for referral to mediation or a review panel. ${ }^{42}$ This scoping stage is of critical importance: if the assessment is not properly scoped, it will be open to subsequent legal challenges.

The factors to be considered are set out in the CEAA. The RA is required to determine the scope of some of these factors, including:

- the environmental effects of the project;

- the significance of the effects;

The RA must provide for the involvement of the public by ensuring that a public registry is established and maintained.

4

While the CEAA is ambiguous on the issue of whether or not the RA must comply with the Minister's recommendation, in practice the RA implements the Minister's decision. The proposed amendments to $C E A A$ make it clear that when the Minister finds that the project should not go ahead, the RA cannot take any action that would allow the project to proceed: Bill C-19, An Act to Amend the Canadian Environmental Assessment Act, 1st Sess., 37th Parl., 2001 (2d reading 4 June 2001) [hereinafter Bill C-19]. 
- the mitigation measures;

- $\quad$ alternative means of carrying out the project;

- follow-up program; and

- capacity of renewable resources. ${ }^{43}$

\section{FirSt DRAFT OF COMPREHENSIVE STUDY REPORT ${ }^{\text {A4 }}$}

When the study is complete, a draft of the Comprehensive Study Report must be prepared by the Proponent and reviewed by the RA:

- $\quad$ to ensure that it meets the project specific guidelines; and

- for scientific and technical accuracy.

The CEAA Guide encourages the RA to involve identified stakeholders (expert federal authorities, provincial and local governments, and members of the public affected by the project, for example) in the review of the Comprehensive Study Report prior to it being submitted to the Agency or the Minister. ${ }^{45}$

It is important that the Comprehensive Study Report provide the RA, and ultimately the Minister, with the information necessary to decide whether or not potential adverse environmental effects associated with the proposed project are significant. As well, the Comprehensive Study Report should indicate how any concerns raised will be addressed so that the decision-makers can determine whether the residual effects are acceptable. ${ }^{46}$

Once the RA has completed its review, it submits a draft form of the Comprehensive Study Report to the Agency for review before it is formally submitted to the Agency and Minister. ${ }^{47}$

\section{SUBMISSION OF COMPREHENSIVE STUDY REPORT TO AGENCY AND MINISTER}

The RA, after considering other federal authorities' comments, the opinions of experts, and comments from the public, finalizes the Comprehensive Study Report for submission to the Agency and Minister. The Comprehensive Study Report reflects the RA's position on the project, indicating that it fully agrees with its content. ${ }^{48}$

The RA will also enclose the responses to notifications sent under the Coordination Regulations and written confirmation from all federal authorities that the necessary factors have been considered and that the Comprehensive Study Report is complete. ${ }^{49}$

CEAA, supra note 2 , s. 16(3).

The contents of the Comprehensive Study Report are analyzed in detail in Part IV, below, in the section dealing with the practical overlap of the two regimes.

CEAA Guide, supra note 8, Step 2.4.

lbid., Step 2.3.

Ibid., Step 2.4 .

Ibid., Step 2.5 .

The RA must take into account any comments received from the federal authorities when finalizing the Comprehensive Study Report: ibid., Step 2.5. 


\section{AgENCy ReVIEW OF THE COMPREHENSIVE StUdy RePORT}

Upon receipt of the final Comprehensive Study Report, the Agency publishes a public notice stating the date of availability of the Comprehensive Study Report, the location to obtain copies of the Comprehensive Study Report, and the deadline and address for filing comments. ${ }^{\text {so }}$

While the Agency has not adopted strict timelines, the period for public comments is usually thirty-five to forty days. ${ }^{\text {s1 }}$ Any public comments received by the Agency will be given to the RA to be filed in the public registry. The Agency staff analyzes the comments received and facilitates the resolution of disagreements that might otherwise cause the project to be referred to assessment by mediation or a review panel. ${ }^{\$ 2}$

The Agency reviews the Comprehensive Study Report to:

- $\quad$ ensure compliance with the $C E A A$, regulations, and the $C E A A$ Guide;

- determine whether the public and federal authorities have been consulted and whether their concerns remain outstanding;

- ensure that sufficient information is available to the public to evaluate the findings; and

- look for major gaps in scientific or technical analysis. ${ }^{53}$

After the Agency has completed its review of the Comprehensive Study Report, any other documents submitted by the RA, and the comments received from the public and other parties, it then summarizes these comments and formulates suitable recommendations for the Minister's consideration.

\section{DECISION BY MINISTER - REFER THE PROJECT BACK TO THE RA FOR ACTION OR TO A PUBLIC REVIEW PANEL OR MEDIATION FOR FURTHER REVIEW ${ }^{\text {S4 }}$}

The Agency's recommendations to the Minister deal with whether the project should be referred back to the RA for action or to a public review panel ("Panel") or to mediation.

CEAA, supra note 2, s. 22(1). This notice should be published within one week of receiving a Comprehensive Study Report according to the CEAA Guide, ibid., Step 3.2.

si According to the CEAA Guide, ibid., Step 3.2, this deadline should be established by the Agency in consultation with the RA, taking into account the scale and complexity of the proposed project, the level of public interest, and the nature and extent of any public consultations held during the preparation of the Comprehensive Study Report.

52 If the Agency cannot achieve consensus, it includes any unresolved issues in its recommendation to the Minister: CEAA Guide, ibid., Step 2.5.

53 The Agency does not do any detailed scientific analysis of the Comprehensive Study Report, but instead relies on the expert input from government departments or independent experts. According to the CEAA Guide, ibid., Step 3.2, this deadline should be established by the Agency in consultation with the RA, taking into account the scale and complexity of the proposed project, the level of public interest, and the nature and extent of any public consultations held during the preparation of the Comprehensive Study Report. 
The Minister must determine:

- if the project is not likely to cause significant adverse environmental effects;

- if the project is likely to cause significant adverse environmental effects without any justification;

- whether there is uncertainty as to the environmental effects of the project; or

- whether the project is likely to cause significant adverse environmental effects, although there may be some justification for these.

If the Minister determines that the first or second circumstance exists, he or she then refers the project back to the RA so that it may implement the Minister's decision. If the Minister determines that the third or fourth circumstance exists, or if public concern warrants it ${ }^{55}$ the Minister refers the project to mediation or a Panel. ${ }^{56}$

It is important that the Comprehensive Study Report be complete because if there are public concerns that have not been addressed, the Minister must refer the project to mediation or a Panel, which will lengthen and add uncertainty to the approval process.

The Minister has the authority to refer the project to mediation or a Panel at any time before approval. ${ }^{57}$ This emphasizes the importance of an ongoing consultation process; it is not only the final Comprehensive Study Report that must be comprehensive in addressing the concerns of the public and the experts but the whole approval process. This also emphasizes the importance of a coordinated public relations campaign by the Proponent to fully address potential concerns in a timely fashion because if public concern warrants it, the Minister can refer the project to a panel at any time.

Under the proposed amendments to the $C E A A$ the possibility of a project being referred to mediation or a Panel, after a comprehensivestudy has been completed, would be removed. As well, the authority of the Minister to refer a project to mediation or a Panel, at any time, would also be removed. Under the suggested revisions, the RA would report to the Minister early in the process ${ }^{58}$ on the ability of a comprehensive study to address the issues related

The factors to be considered in deciding whether or not public concerns warrant a referral to a mediator or a panel were set out in Cantwell v. Canada (Minister of the Environment), [1991] 41 F.T.R. 18 (N.S.). These factors include the level and extent of public concern, the general conclusion of the environmental assessment that expressly refers to public concerns, evidence of widespread public concern, advice to the Minister that the environmental effects which are causing public concern are considered insignificant or mitigable with known technology, the lack of likely effectiveness of a panel to address the concerns of the public, and the effectiveness of the RA's efforts to obtain a full and accurate view of public concerns associated with the project and to deal with these concerns in their report. The Court found that the following factors were irrelevant: considerations of expediency or practicality, the fact that construction had begun on the project, and the fact that the provincial government, having concluded its own assessment, would be unlikely to agree to participate in a public review. CEAA, supra note 2, s. 23.

37 Under the CEAA, ibid., s. 28, if at any time the Minister is of the opinion that the project may cause significant adverse environmental effects or that public concerns warrant it, the Minister may, after consultation with the jurisdiction in which the project is to occur and the RA, refer the project to a mediator or review panel. 
to the project. If the Minister accepts the RA's recommendation to proceed by way of comprehensive study, no subsequent referrals to a Panel would be possible. ${ }^{59}$

\section{Mediation OR Panel Reviews}

If a project is referred to a Panel or mediation, the scope of the environmental assessment of the project may change, ${ }^{60}$ which would further delay the approval process.

Mediation will only be selected if all interested parties have been identified and are willing to participate in a mediation. ${ }^{61}$ If mediation is chosen, the mediator is appointed by the Minister (after consultation with the RA and all participating parties) and the Minister sets the terms of reference..$^{62}$ If the mediation is completed, the mediator prepares and submits a report to the Minister and the RA. ${ }^{63}$

If it appears that the mediation will not likely produce a result satisfactory to all parties, the Minister may terminate the mediation and refer the issue to a Panel. ${ }^{64}$ The contents of the mediation are not admissible before a Panel or court without the consent of the mediator and the participant. ${ }^{\text {ss }}$

If the Minister chooses to refer the project to a Panel, the Minister appoints the members - in consultation with the RA - and sets its terms of reference. ${ }^{66}$ The Panel then ensures that the information required for assessment is obtained and made available to the public. ${ }^{67}$ It then holds public hearings in a manner that offers the public an opportunity to participate in accordance with the Panel's terms of reference. If an issue arises before the Panel that would be best solved through mediation, the Minister may, after consultation with the Panel, refer the issue to a mediator. ${ }^{68}$

The Panel prepares a report, stating its conclusions and recommendations and includes a summary of comments received from the public. This report is then submitted to the Minister

Bill C-19, supra note $41, \mathrm{cl} .13$.

Under s. 15(2) of the CEAA, supra note 2, the Minister decides the scope of project when a Panel or mediation is used, but does so in consultation with the RA. As well, the CEAA is clear that the mediator or the Panel may have all of an environmental assessment referred to it or just part: ibid., s. $29(1)$.

Ibid., s. 29(2).

Ibid., s. 30(1).

Ibid., s. 32.

Ibid., s. 29(4). Bill C-19, supra note 41, cl. 15 suggests that this section be replaced by a new section, which would state that when the mediator or the Minister feels that the mediation is not likely to produce a result satisfactory to all participants, the Minister is to order the conclusion of the mediation. This change would have greater certainty for participants because referral under the old version of the CEAA from mediation to a Panel would lengthen the approval process and add uncertainty to the approval date.

CEAA, ibid., s. 32(2).

Ibid., s. 33(1).

Unless the Panel is satisfied that "direct and substantial harm would be caused to the witness by the disclosure of the evidence," ibid., s. 35(3). If that is the case, the evidence given is privileged and shall not be disclosed without authorization of the witness. ibid., s. 35(4).

Ibid., s. 29(3). 
and the RA. ${ }^{69}$ The Minister ensures that the report is made available to the public. ${ }^{70}$ If the Panel recommends approval of the project, the report includes mitigation measures and a follow-up program. ${ }^{71}$

When appointing the Panel, the Minister has the discretion to appoint a joint panel ("Joint Panel"). This would be done when another jurisdiction ${ }^{72}$ has the responsibility or authority to conduct an assessment of the environmental effects of the project. ${ }^{73}$ Oil and gas developments in the Newfoundlandoffshore do involve another jurisdiction, the CNOPB and the Newfoundland government, for example. The Joint Panel is created by agreement, which also sets out the manner in which the assessment is to be conducted. ${ }^{74}$

A Joint Panel would not only address overlap between the Accord Implementation Acts' approval process and the $C E A A$ approval process, but it would also address the jurisdictions of the Province of Newfoundland and Labrador and the federal government in an offshore development project. The provincial Environmental Assessment Act ${ }^{75}$ would have application to any onshore or near shore activities related to an oil and gas development in the offshore. The provincial $A c t$ provides for its own method of environmental assessment. However, the provincial $A c t$ also allows for a project to be exempt from this procedure when the Minister responsible for the environment is of the opinion that it would be in the public interest to do so. ${ }^{76}$ An agreement to utilize a Joint Panel could include provision for such an exemption."

\section{ACTION BY RESPONSIBLE AUTHORITY}

Whether or not the project is immediately referred to the RA or is referred to a Panel or mediation for further review, the final step in the approval process is action by the RA.

The action taken by the RA does not involve any decision-making authority, but instead is simply an implementation of the Minister's decision. If the Minister makes a determination that the project is not likely to cause significant adverse environmental effects, ${ }^{78}$ for

Ibid., s. 34 .

Ibid., s. 36.

Ibid., s. 34(c). When a Panel or mediation has been used, Cabinet must approve the Comprehensive Study Report before the RA may take any action that would allow the project to proceed, ibid., s. 37.

Defined by s. $40(1)$ of the $C E A A$, ibid, as a federal authority; the government of a province; an agency or body established pursuant to an act, that has powers, duties or functions in relation to an assessment of the environmental effects of a project; any body established pursuant to a land claims agreement; a government or institution of a foreign state; or an international organization of states. Ibid., s. 40(2).

Any agreement on the use of a Joint Panel shall be published before the hearings commence, ibid., s. 40(4). As well, the conditions imposed upon a Joint Panel and the method of appointing the Panel are set out in detail in s. 41 of the CEAA.

R.S.N. 1990, c. E-14.

Ibid., s. 37. Approval of the Lieutenant Governor in Council is required for this exemption. This procedure was used for the environmental assessment of the Terra Nova Project, described below.

While the CEAA says the RA makes this determination, it is the Minister who holds the decisionmaking power. As noted above, this ambiguity is resolved by the proposed amendments under Bill C-19, supra note 41 . 
example, the RA must perform its function or exercise its power listed under s. $5 .^{79}$ Likewise, if the Minister determines that the project is likely to cause significant environmental effects that cannot be justified, the RA shall not perform its function or exercise its power listed under s. 5 .

The determination of the Minister to allow the project to proceed shall not be made until the Minister or the RA has received all responses to notices sent under $\mathbf{s}$. 5 of the Coordination Regulations and has received written confirmation from all federal authorities involved in the environmental assessment that the factors set out were considered and that the Comprehensive Study Report is complete. ${ }^{80}$

The public is advised of:

- the RA's course of action in relation to the project;

- any mitigation measures to be implemented;

- the extent to which recommendations of the mediator or Panel were adopted, and any reasons why recommendations were not adopted; and,

- any follow-up program to be implemented and any results therefrom. ${ }^{81}$

When the decision is made not to allow the project to proceed, the RA files a notice of its course of action in the public registry. ${ }^{82}$ But the responsibilities of the RA do not end there. It is the RA who is responsible to ensure the implementation of mitigation measures and the follow-up plan..$^{83}$

\section{ROLE OF THE AgenCy}

The Agency was created under the $C E A A$ to advise and assist the Minister. The Agency, through its president, ${ }^{84}$ may exercise all of the powers of the Minister under the $C E A A$ as authorized by the Minister. ${ }^{85}$ Therefore, the Agency's role in the approval process must be understood in order to accurately assess the system.

The Agency's objectives are to:

- administer the environmental assessment;

- $\quad$ promote uniformity and harmony;

- promote or conduct research;

- $\quad$ promote assessments consistent with the purposes of the $A c t$; and

The Minister has issued guidelines that establish criteria for making the determination of whether or not the project will have significant environmental effects and whether or not these effects are justified in the circumstances under the CEAA, supra note 2, s. 58(1): "Reference Guide: Determining Whether a Project is Likely to Cause Significant Adverse Environmental Effects," online: Government of Canada <www.ceaa.gc.ca/001 1/0001/0008/guide3_e.htm> (date accessed: 2 January 2002).

\$) Supra note 31, s. 10.

81 CEAA, supra note 2, s. 38(2).

82 Ibid., s. 37(3)(a).

83 Ibid., s. 38(1).

84 Appointed by the Governor in Council, ibid., s. 65(1).

8s Ibid., s. 65(2). 
- ensure an opportunity for public participation. ${ }^{86}$

The roles of the Agency regarding comprehensive studies include:

- assisting in coordination among federal authorities;

- identifying expert authorities to review and provide input on the Comprehensive Study Reports;

- providing advice on the scope of the assessment;

- facilitating the resolution of disagreements among the federal authorities; and

- assisting in appointing the RA.

Once the Comprehensive Study Report is in its final draft form, the Agency reviews it to determine compliance with statutory, regulatory, and policy guidelines. Once the final Comprehensive Study Report is ready, it is formally submitted to the Agency and the Minister, and the Agency formulates suitable recommendations for the Minister's consideration on the need for further assessment.

Seeking early and ongoing assistance from the Agency has several important benefits, including:

- ensuring that unforeseen developments or relatively minor issues do not unnecessarily trigger the need for a costly, time consuming public review;

- [avoiding] the need for additional information requests late in the process; and,

- [reducing] the Agency's time to review the [C]omprehensive [S]tudy [R]eport. ${ }^{87}$

The CEAA allows the public to have an ongoing role in the approval process. It is the Agency's role to ensure that the public notification and consultation requirements under the Act are met. As well, the Agency is responsible, with input from the Proponent, to develop a public involvement plan. The CEAA Guide suggests methods to achieve early and meaningful public involvement, which include:

- $\quad$ holding community meetings;

- receiving information and comments from the public;

- discussing issues and clarifying positions and concerns with the public;

- building consensus among key groups or individuals affected by the project; and

- informing participants of results and decisions. ${ }^{88}$ 


\section{Practical OVerlap - How the Two Systems Fit Together}

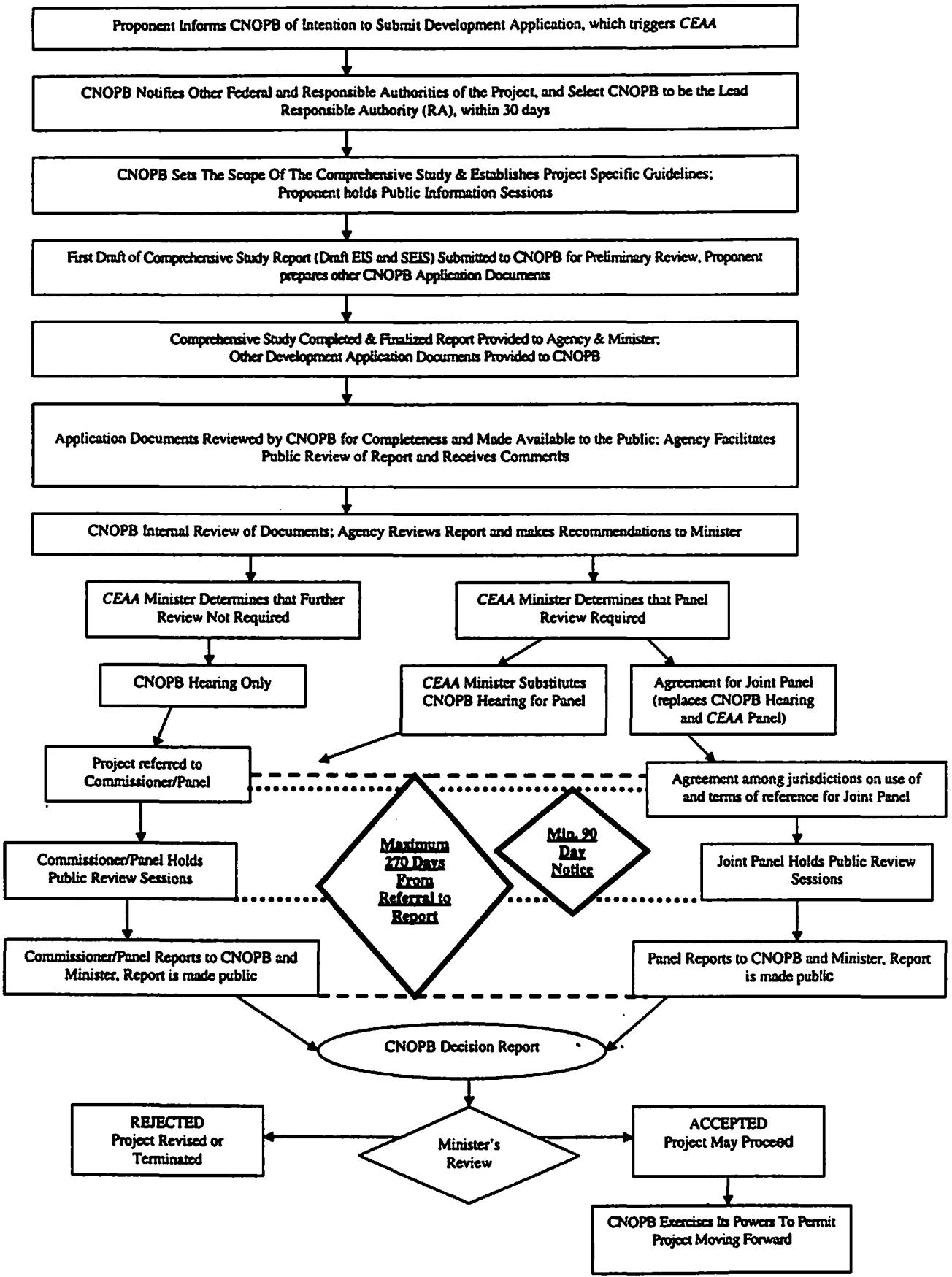


One of the legislated goals of both approval regimes is to avoid unnecessary duplication. For this goal to be accomplished, the legislation and guidelines must allow for a certain degree of overlap in practice.

The Accord Implementation Acts allow for little or no flexibility in their application:

s. 4 In case of any inconsistency or conflict between

(a) this Act or any regulations made thereunder. and

(b) any other Act of Parliament that applies to the offshore area or any regulations made under that Act,

this Act and the regulations made thereunder take precedence. ${ }^{89}$

In contrast, the $C E A A$ allows for regulations to be made ${ }^{90}$ that vary or exclude any procedure or requirement of the environmental assessment process ${ }^{91}$ for the purpose of adapting the $C E A A$ process to projects where the CNOPB exercises an approval power.

As well, the $C E A A$ states that where a jurisdiction has a responsibility or an authority to conduct an assessment of the environmental effects of the project, the Minister must offer to consult and co-operate with that other jurisdiction regarding the assessment of the environmental effects of the project. ${ }^{92}$

Therefore, to find a point of possible convergence between the two approval regimes, it is logical to attempt to subsume the CEAA procedure within the CNOPB approval process.

One way to accomplish this is to fold the environmental assessment process into the document submission and public review under the Development Plan application. This would require:

- examining the factors to be assessed under each process to determine if they are compatible;

- determining if the CNOPB can act as the RA;

- ascertaining whether the timelines under each system are compatible; and

- ensuring that the role of the public in the decision-making process is not diminished.

\section{A. Past Practice}

In the past this convergence has been accomplished through the use of a Joint Panel established by project-specific memoranda of understanding ("MOU"). As well, pursuant to the Canada-Wide Accord on Environmental Harmonization, in 1988 the provincial and 
federal governments ${ }^{93}$ entered into a general MOU regarding environmental assessments, called the Sub-Agreement on Environmental Assessments. This MOU provides that the CNOPB will be the lead agency ${ }^{94}$ and that the Newfoundland and Labrador Department responsible for the environment will act as a principal advisor to the CNOPB. ${ }^{95}$ The MOU indicates that the CNOPB will ensure that all parties are informed of any public review processes to be undertaken and will ensure, consistent with the time constraints established by the Accord Implementation Acts, that sufficient notice is given to permit them to prepare for the process. ${ }^{96}$

The environmental assessment of the Terra Nova Project was done by way of a joint public review panel. The MOU indicated that the comprehensive study step would be eliminated. ${ }^{97}$ The MOU merged the documentary requirements of the two approval regimes by requiring the proponent to submit, in support of its development application, an EIS, an SEIS, and a consideration of factors listed in s. 16 of the $C E A A .{ }^{98}$ The Panel was comprised of candidates nominated by both the federal and provincial governments and, after completion of the public hearings, the Panel submitted its report to the CNOPB, the Minister of Natural Resources, the Minister of Mines and Energy, the Minister of the Environment, and the Minister of Environment and Labour. ${ }^{99}$ The role of the public in the environmental assessment process was not diminished by the MOU for the Terra Nova Project. The report of the review Panel was made available to the public by the CNOPB. Comments from the public on the documentation were part of the Panel's consideration. ${ }^{100}$ These comments were received during the prescribed timeframe for comments (not less than thirty days and not more than sixty days before the commencement of public hearings). ${ }^{101}$

The environmental assessment of the Terra Nova Project adopted the timelines set by the Accord Implementation Acts for the panel review. The MOU indicated that the panel's report was to be submitted at the earliest date and in no event later than 270 days following the receipt of the application and supporting documents by the panel. ${ }^{102}$

The environmental assessment carried out for the Hibernia Project also involved a Joint Panel. The terms of reference for the panel were developed jointly by both levels of government. ${ }^{103}$ The approval procedure, as set out in the terms of reference, indicated

This MOU was entered into by the CNOPB, Environment Canada, the Canada Oil and Gas Lands Administration of the Department of Energy, Mines and Resources, the Newfoundland and Labrador Department of Environment and Lands, the Newfoundland and Labrador Department of Energy, and the Newfoundland and Labrador Inter-Governmental Affairs Secretariat. See CNOPB Homepage, online: <www.cnopb.nfnet.com>. Ibid., cl. 1.1.

Ibid., cl. 1.3.

Ibid., cl. 8.

Ibid., cl. 2.2 .

Ibid., cl. 3.1.

Ibid., cl. 7.1 .

Ibid., Annex III, cl. 2.

Ibid., Annex III, cl. 10, 13.

Ibid., Annex III, cl. 14.

The terms of reference are set out in Appendix B of the Panel's report. 
that the EIS was distributed to the public, government departments, and agencies. Public information sessions were held and the government conducted an internal review of the EIS. The environmental assessment then proceeded to public hearings, and a final report was submitted to the responsible provincial and federal Ministers and to the CNOPB.

The timeline for the Hibernia assessment, like the Terra Nova assessment, reflected the timelines set out in the Accord Implementation Acts - 230 days between the time that the panel was provided with the EIS and the time they produced their report.

\section{B. SUGgeSTIONS FOR THE FUTURE}

The more direct method of avoiding duplication is to have the Minister use his or her authority under the $C E A A$ to substitute the public review hearings of the CNOPB for the Panel review called for under the $C E A A .^{104}$ This substitution must be done in writing ${ }^{105}$ and shall not occur unless:

- the other process considers the same factors;

- the public is given the opportunity to participate;

- a report is generated and given to the Minister and is published; and

- $\quad$ any criteria set by the $C E A A$ Minister are met. ${ }^{106}$

As will be shown below, the factors considered in the two reviews mirror each other, and one review would not diminish the role of the public. As for the necessity of a report, the CNOPB procedure already requires that the Panel or commissioner submit a report to the CNOPB and to both Ministers after the conclusion of the hearings. This CNOPB hearing report could also be sent to and approved by the federal Minister of the Environment.

This substitution may be done on a project-by-project basis or for a class of projects. ${ }^{107}$ Once the $C E A A$ Minister has determined that the CNOPB public review process meets the required criteria, he or she can approve its substitution on all oil and gas developments in the Newfoundland offshore. While one is not required, the CEAA Minister may wish to have an MOU between the various federal authorities, responsible authorities, and both levels of government involved in the environmental assessment of projects in the Newfoundland offshore.

\section{FACTORS TO BE CONSIDERED}

Since the hypothesis is to envelop the $C E A A$ procedure inside the CNOPB procedure, a list of the requirements under the $C E A A$ approval process may be cross-referenced with the requirements of the CNOPB procedure. As is set out in detail below, each of the 
$C E A A$ factors are captured by the CNOPB documents, and merging the two approval systems would not diminish the scope of either.

The $C E A A$ requires the comprehensive study to consider:

- environmental effects, including malfunctions or accidents and any cumulative effects from the combination of the project and other projects or activities that have been or will be carried out;

- the significance of these environmental effects;

- comments from the public received in accordance with the $\mathrm{Act}$ and the regulations;

- measures that are technically and economically feasible and that would mitigate any significant adverse environmental effects;

- any other matter relevant to the comprehensive study, mediation or assessment by the review panel that the RA or the Minister may require to be considered;

- the purpose of the project;

- alternative means of carrying out the project that are technically and economically feasible and the environmental effects of those alternatives;

- the need for, and the requirements of, any follow-up program; and

- The capacity of resources that are likely to be significantly affected by the project to meet the needs of the present and the future. ${ }^{108}$

The documents required by the CNOPB process that are most likely to address these factors are the EIS and the SEIS. If we take each of the nine factors ${ }^{109}$ listed we can find that each is encompassed by the CNOPB process.

\begin{tabular}{|l|l|}
\hline \multicolumn{1}{|c|}{ FACTORS CONSIDERED UNDER CEAA } & PARALLEL COMPONENTS OF CNOPB PROCESS \\
\hline $\begin{array}{l}\text { 1. Environmental effects of the project, and } \\
\text { their significance. }\end{array}$ & $\begin{array}{l}\text { EIS - "Description of Existing Environment" and } \\
\text { "Environmental Effects" sections. }\end{array}$ \\
\hline $\begin{array}{l}\text { 2. Environmental effects from malfunctions or } \\
\text { accidents and their significance. }\end{array}$ & $\begin{array}{l}\text { EIS - "Description of Existing Environment," } \\
\text { "Environmental Effects," and "Mitigation and } \\
\text { Monitoring" sections. }\end{array}$ \\
\hline $\begin{array}{l}\text { 3. Cumulative effects from the combination of } \\
\text { the project and other projects or activities } \\
\text { that have been or will be carried out. }\end{array}$ & $\begin{array}{l}\text { EIS - "Environmental Effects" section; } \\
\text { SEIS. }\end{array}$ \\
\hline
\end{tabular}

Ibid., s. 16(1)-16(2). The scope of these factors is determined by the RA for comprehensive studies and by the Minister, in consultation with the RA, for mediations and assessments by Panels, ibid., s. 16(3).

Excluding number five, which cannot be accurately predicted for comparison purposes. However, given the legislative goal of overlap and the extensiveness of the factors considered by a development application, it seems unlikely that any factor would be required by the RA or the Minister that would not be captured. 


\begin{tabular}{|c|c|}
\hline FACTORS CONSIDERED UNDER CEAA & PaRALLEL Components OF CNOPB PROCESS \\
\hline $\begin{array}{l}\text { 4. Comments from the public received in } \\
\text { accordance with the } C E A A \text { and regulations. }\end{array}$ & $\begin{array}{l}\text { Two examples from the CNOPB procedure: } \\
\text { consultation with residents of communities affected } \\
\text { when preparing the SEIS and review by the panel } \\
\text { or commissioner of any comments received from } \\
\text { the public before the hearings commence. }\end{array}$ \\
\hline $\begin{array}{l}\text { 5. Technically and economically feasible } \\
\text { measures that would mitigate any significant } \\
\text { adverse environmental effects. }\end{array}$ & EIS - “Mitigation and Monitoring" section. \\
\hline 6. The purpose of the project. & Development Plan. \\
\hline $\begin{array}{l}\text { 7. Technically and economically feasible } \\
\text { alternative means of carrying out the project } \\
\text { and the environmental effects of those } \\
\text { alternatives. }\end{array}$ & $\begin{array}{l}\text { EIS - "Environmental Effects" section; } \\
\text { Development Plan. }\end{array}$ \\
\hline $\begin{array}{l}\text { 8. The need for, and the requirements of, any } \\
\text { follow-up program. }\end{array}$ & $\begin{array}{l}\text { EIS - "Residual Effects" and "Environmental } \\
\text { Effects" sections. }\end{array}$ \\
\hline $\begin{array}{l}\text { 9. The capacity of resources that are likely to } \\
\text { be significantly affected by the project to } \\
\text { meet the needs of the present and the future. }\end{array}$ & $\begin{array}{l}\text { EIS - "Description of Environment" section; } \\
\text { SEIS - analytical scope. }\end{array}$ \\
\hline
\end{tabular}

\section{a. Environmental Effects of the Project and their Significance}

Part, if not all, of the EIS deals with this consideration. Specific examples can be found in the "Description of Existing Environment" section and the "Environmental Effects" section. Under the heading "Description of Existing Environment," the EIS must provide a baseline description of the biological environments within the area potentially affected by the project, as it exists prior to project development, focusing on those elements that are likely to significantly affect or be affected by the project. ${ }^{10}$ In the "Environmental Effects" section, the EIS includes systematic identification of interactions between the project and the physical, biological, and geological environments within the project area and the spatial extent of predicted effects. ${ }^{\prime \prime}$

\section{b. Environmental Effects from Malfunctions and Accidents, and their Significance}

In the "Description of Existing Environment" section, the EIS deals with the shoreline environment and outlines geomorphic processes that could potentially be affected by spills or by associated land-based activities." In the "Environmental Effects" section of the EIS, the subsection called "Project Effects" deals with the effect of oil discharges on seabirds and the fishery, disposal of liquid wastes, atmospheric conditions, seabed disturbances, solid waste discharges, noise levels, and supply sources for construction 
materials, including water. ${ }^{1 / 3}$ As well, in the "Environmental Effects" section, the EIS deals with major oil and/or chemical spills, providing a detailed assessment of probability and potential effects of spills. Considerations in this section include:

- the probability of occurrence;

- type;

- flow rate and duration of spill;

- characteristics;

- behaviour and fate of spilled hydrocarbon;

- $\quad$ effect on birds, fish, mammal, plant life, shoreline; and

- potential effect on the fishing industry. ${ }^{1 / 4}$

In the "Mitigation and Monitoring" section of the EIS there is a description of contingency planning and countermeasures (to the level of detail possible at the time of the application). This description includes:

- types of emergencies for which a contingency plan will be in place;

- general emergency response organization (chain of command and areas of responsibility);

- internal and external notification and reporting procedures;

- relationship between the Proponent's plans and other operators or government agencies;

- training of personnel;

- $\quad$ personnel and equipment requirements;

- $\quad$ response timing and anticipated equipment inventory for spill surveillance;

- tracking, containment, and cleanup;

- capabilities and limitations of countermeasures;

- research and development programs that may increase efficiency or capability of plans;

- $\quad$ relief well drilling;

- monitoring program for significant effects; and

- plans for disposal of recovered pollutants and debris. ${ }^{115}$

c. Cumulative Effects from the Combination of the Project and

Other Projects or Activities that Have Been or Will Be Carried Out

The Environmental Effects section of the EIS deals with the cumulative environmental effects of the project. The SEIS also addresses cumulative effects from other known major industrial projects. 
d. Comments from the Public Received in Accordance with the $C E A A$ and Regulations

Two examples of how the CNOPB procedure provides for participation by the public are: when preparing the SEIS, the Proponent consults with residents of communities affected to identify issues which are of most concern to them, and gives those issues particular attention, ${ }^{116}$ and when the public review hearings are carried out, the panel or commissioner reviews any comments received from the public before the hearings commence. ${ }^{117}$

e. Technically and Economically Feasible Measures that would Mitigate any Significant Adverse Environmental Effects

The "Mitigation and Monitoring" section of the EIS reviews procedures and equipment proposed to be used to prevent the possible harmful effects of the project on the environment. As well, it includes a discussion of compensation plans and financial security for the clean up of spills. ${ }^{118}$

\section{f. The Purpose of the Project}

The CEAA Guide requires a description of the objectives of the project and states that "[i]f the objectives of the project are related or contribute to broader private or public sector policies, plans or programs, this information should also be included to assist in placing the project's objectives in a broader and more meaningful context." 119

While the development application documents do not specifically deal with this factor, the objective or purpose of the project when dealing with oil and gas development is selfevident, and if not, can be addressed in the Development Plan.

g. Technically and Economically Feasible Alternative Means of Carrying Out the Project and the Environmental Effects of those Alternatives

The "Environmental Effects" section of the EIS deals with significant differences in the environmental effects of alternative approaches to development. ${ }^{120}$ As well, the Development Plan discusses the alternative exploitation schemes, the production and transportation systems considered, and the rationale for selecting the proposed approach. ${ }^{12 !}$ 
h. The Need for, and the Requirements of, any Follow-Up Program

In the EIS the "Residual Effects" section discusses the expected environmental condition of the area after all mitigative measures have been incorporated. It includes a discussion of the nature, extent, and duration of the environmental effects of the project. ${ }^{122}$ The "Environmental Effects" section sets out requirements for further monitoring, research or data collection. ${ }^{123}$

The EIS also addresses compliance and environmental effects monitoring by outlining the Proponent's plan to monitor compliance with government requirements and the effect on the environment. The Proponent's physical environmental observation program is established to gather data concerning the physical environment during the project, including any points of interface with government measurement programs. The Proponent's forecasting programs are used for the operational prediction of environmental conditions during and after the project. ${ }^{124}$

i. The Capacity of Resources that are Likely to be Significantly Affected by the Project to Meet the Needs of the Present and the Future

In the "Description of Existing Environment" section of the EIS, the Proponent must include a description of the biological environment, with an emphasis on ecological processes and its role in the stability, variability, and resiliency of the various species in that ecosystem. ${ }^{125}$ The analytical scope of the SEIS includes assessing the impact on land and resource use. ${ }^{126}$

\section{j. Conclusions}

The requirements under the approval process administered by the CNOPB are indeed broad enough to satisfy the factors that must be considered in the comprehensive study under the $C E A A$. Therefore, the factors considered under each system are compatible with each other.

When the systems are successfully integrated, the comprehensive study will take the form of an environmental impact statement and socio-economic impact statement, as has occurred on the White Rose Project. The comprehensive study is not based on the environmental impact statement and socio-economic impact statement but instead is the environmental impact statement and socio-economic impact statement. 


\section{CNOPB AS RA}

The second step in trying to merge the two approval regimes is determining whether the CNOPB can act as the RA under the CEAA. As set out below, the CNOPB may (or perhaps must) act as the RA under the $C E A A .^{127}$

The $C E A A$ requires that before a federal authority exercises one of the powers listed in $\mathrm{s} .5$ an environmental assessment must be carried out. ${ }^{128}$ The federal authority that exercises one of the powers listed is responsible for ensuring that this environmental assessment is carried out and is referred to as the responsible authority.

The Federal Authorities Regulations ${ }^{129}$ prescribe the CNOPB to be a federal authority under the $C E A A$. The CNOPB exercises one of the powers listed in s. $5 .{ }^{130}$ Therefore, the CNOPB is a responsible authority under the $C E A A$ and would most likely be selected as the lead RA.

\section{TIMELINES}

The third step in finding overlap in the two approval regimes is ascertaining whether the timelines under each system are compatible. Since there are no relevant timelines under the $C E A A$, there is no difficulty adopting the CNOPB timelines.

The strictest timeline of the two approval regimes is set by the Accord Implementation Acts. Once the panel or commissioner is appointed for the public review and a notice is published, the hearings are to be held a minimum of ninety days from the time of the notice. ${ }^{131}$ This provision guarantees time for the public to review the application, submit requests for information and participate in the hearings.

Even if the CNOPB did not qualify as an RA, the RA can delegate "to any person ... any part of the ... comprehensive study of a project or the preparation of the...comprehensive study report, and ... any part of the design and implementation of a follow-up program." For example, the RA could delegate to the CNOPB: CEAA, supra note 2, s. 17.

Ibid., s. 5.

129 S.O.R.96/280.

13i) There is debate surrounding the exact subsection of s. 5 to be relied on (s. $5(1)$ is set out in full in note 34). Members of the industry believe that the environmental assessment procedure under the $C E A A$ is triggered because the CNOPB grants an interest in land (the Newfoundland offshore) which it administers, when it approves a Development Plan: s. 5(1)(c). The question is whether approval of a Development Plan is "granting an interest in land." The other possible ground of authority is that the CNOPB is granting an approval under s. $5(1)(d)$. There is a technical difficulty with reliance on s. 5(1)(d), however, because the approval of a Development Plan under the Federal Accord Implementation Act, supra note 1 is not included in the Law List Regulations, supra note 34. This must have been an oversight as the approval of a Development Plan is directly analogous to the other approvals listed therein. As well, other provisions of the $C E A A$ deal with projects administered by the CNOPB (such as s. 59(i)(v)); the CNOPB is listed as a federal authority under the Federal Authorities Regulations; and in practice, the CNOPB treats a Development Application approval as a trigger for an environmental assessment under the $C E A A$. 
The more significant deadline for the Proponent states that when the panel or commissioner receives the development application documents from the CNOPB, their report must be submitted within 270 days from the time of receipt of the information. ${ }^{132}$ This timeline provides certainty to the approval process by setting a final date for everyone involved.

The $C E A A$, on the other hand, does not provide such certainty, which is one of the reasons why it is preferable to collapse it into the CNOPB system.

The only significant indication of a timeline provided in the CEAA states that the environmental assessment is to be carried out as early as is practicable in the planning stages of the project before irrevocable decisions are made. ${ }^{133}$ To date this timeline has not been given judicial consideration. ${ }^{134}$

The only other timelines deal with the determination of whether an environmental assessment is required, a consideration which is irrelevant in the case of oil and gas developments. Even these can be changed, however, if they conflict with timelines under another $A c t .^{135}$

The other relevant timeline deals with the period from the time of the submission of the report to the Agency to the time of a decision by the Minister regarding referral to mediation or a Panel. According to the CEAA Guide, the Agency will strive to provide the RA with a determination by the Minister (as to whether the project needs to be referred to a mediator or a Panel) within sixty days of the submission of the final report to the Agency. ${ }^{136}$ The CEAA Guide also states that within one week from receipt of the report, the Agency is to publish a public notice, and that then there is usually thirty-five to forty days for the public to respond with comments. ${ }^{137}$

Since there are no time limits on the Panel or mediation under the $C E A A$, referral to a Panel or mediation could delay both the approval process under the $C E A A$ and the project. If, however, the Panel is replaced by accepting the public hearings conducted by a commissioner or panel under the Accord Implementation Acts, the 270-day limit will apply, and the Proponent will have the certainty that is so valuable to it.

\footnotetext{
132 Federal Accord Implementation Act, supra note 1, s. 144(4).

133 CEAA, supra note 2, s. 11(1).
}

134 It is similar, however, to s. 3 of the Environmental Assessment and Review Process Guidelines Order, S.O.R./84-467 (the predecessor to the CEAA). While the Environmental Assessment and Review Process Guidelines Order has been judicially considered, the Court has not provided much direction on the meaning of this timeline. In Friends of the Island v. Canada (Minister of Public Works), [1993] 10 C.E.L.R. 204 (T.D.), (1995) 18 C.E.L.R. (N.S.) 1 (F.C.A.), Reed J. stated that an assessment of a generic bridge proposal (i.e., before specific details were available) was no substitute for an assessment of a specific bridge proposal. 


\section{ROLE OF THE PUBLIC}

Both of these regulatory approval regimes call for public involvement in the decisionmaking process. Before the two systems can be combined, it must be ensured that the role of the public in the decision-making is not diminished in the process. As outlined below, the role of the public would not be diminished by the merger of the two systems:

The fundamental feature of public involvement is two way communication. That is, it goes beyond simply providing information to the public: there must be an opportunity for the public to provide information back to the decision-maker. ${ }^{138}$

Early and meaningful involvement of the public under the $C E A A$ approval process reduces the need for, or the length of, an expensive public review process. While the public review process is essentially unavoidable under the CNOPB approval structure, the benefits of early and meaningful involvement are not without merit. In fact, the benefits of public involvement that are listed under the $C E A A$ Guide for the $C E A A$ are equally as applicable to involvement of the public with the CNOPB's decision-making process. These benefits are:

- $\quad$ strengthening the quality and credibility of environmental assessments;

- enabling decision-makers at an early stage to identify and address concerns;

- recognizing the public as an important source of local and traditional knowledge;

- building awareness and understanding and helping to identify options or alternatives that are likely to meet with community approval;

- developing the credibility and trust in the decision-making process, which is needed for a consensus;

- building a sense of public trust and credibility in the RA's decisions;

- reducing the possibility that public concerns will lead to costly delays in project approvals and implementation; and

- facilitating better decisions by the RA. ${ }^{139}$

If the two systems were to be merged by using the Proponent's EIS and SEIS as the comprehensive study, for example, or even by substituting the CNOPB hearing process for the Panel under the $C E A A$, an understanding of the role of the public under each $A c t$ is required before we can ensure that it is not diminished by the merger.

The public's role in the mediation or Panel stage of the CEAA assessment begins with reviewing the information that has been provided to the Panel or mediator. This information is made available to the public through the registry and active participation in the hearings, which are held publicly. The report of the mediator or Panel, which includes a summary of any comments received from the public, ${ }^{140}$ is made available to the public by the Minister. ${ }^{141}$

lbid.

CEAA, supra note 2 , s. 34 .

Ibid., s. 36. 
This participation by the public in the $C E A A$ process is organized in the public involvement plan, which is drafted early in the process by the Agency, with input from the Proponent.

Under the CNOPB process, the public has access to documents throughout the application process and are consulted on a regular basis. Specifically, the "CNOPB Guidelines" provide for consultation with affected communities as part of the preparation of the SEIS. As well, the development application summary is made widely available to the public. All development application documents are made available to the public so that comments may be made at the public review hearings. The only exception to this is any proprietary studies or reports filed under Part II of the Development Plan. These are not available for public examination. ${ }^{142}$

Public involvement during the hearing process involves receipt of notice of the hearings to be held by the panel or commissioner and participation in the hearings by making written submissions as interveners. ${ }^{143}$

\section{a. Participant Funding}

To encourage participation in the mediation or Panel stages, the CEAA requires that the Minister establish a participant funding program. ${ }^{144}$ While no such requirement exists in the Accord Implementation Acts, it has been the practice for funding to be provided. In the Terra Nova Project, for example, the Proponent supplied $\$ 63,000$ to the government, which was distributed to various individuals and groups. In the White Rose Project, the Proponent has agreed to reimburse the government for up to $\$ 100,000$ for intervener funding. So, while the merger may lead to a reduction of benefits to the public participants, the informal procedure under the CNOPB approval process will address this concern.

\section{b. Registry}

The other focal point of public involvement under the $C E A A$ is the public registry. Since the Accord Implementation Acts do not give specifics about the CNOPB registry, the $C E A A$ registry could be used in a merged approval process.

\footnotetext{
142 CNOPB Guidelines, supra note 9, c. 1.1.

143 This requirement can be waived by the CNOPB according to CNOPB Guidelines, ibid., c. 2.5.

14* CEAA, supra note 2, s. 58(1.1). The "Reference Guide for Proponents on the Cost Recovery of Environmental Assessement Review Panels," online: Government of Canada <www.ceaa-acee.gc/ 001/index_e.html> (date accessed: 2 January 2002) published by the Agency and sets out how these costs are recovered from the Proponent by the federal government. This funding program would be extended to include the comprehensive study stage of the review as well if Bill C-19, supra note 41 , is accepted.
} 
The $C E A A$ registry is maintained by the RA from commencement of the environmental assessment up to completion of the follow-up program. ${ }^{145}$ The registry must contain:

- all records produced, collected or submitted regarding the environmental assessment;

- $\quad$ any assessment report;

- comments filed by the public;

- $\quad$ any records prepared by the RA for a follow-up program;

- $\quad$ any records produced from a follow-up program;

- the terms of reference for a mediator or Panel; and

- the mitigation measures documents.

Such documents are only included in the registry if they have otherwise been made available to the public and the RA determines the information would have to be disclosed under the Access to Information Act. ${ }^{146}$ Information that would otherwise not be subject to disclosure under the Access to Information Act, however, is included in the registry if the RA or Minister believes on reasonable grounds that disclosure would be in the public interest because such information is necessary for effective participation by the public. ${ }^{147}$ This exception does not apply to third party information. ${ }^{148}$

Bill C-19 proposes that a new Canadian Environmental Assessment Registry be established in place of the current public registry. ${ }^{149}$ According to the Minister's report on Bill $\mathrm{C}-19$, this registry would be a single, government-wide electronic registry administered by the Agency. The amendments to the CEAA proposed by Bill C-19 would clarify which documents are to be filed in the registry and whose responsibility they would be.

To successfully collapse the CEAA approval procedure into the CNOPB's, the Proponent must find a way to satisfy the public notice and participation requirements of both. One solution is to work with the Agency in the development of a public involvement plan that incorporates the needs of both systems. As well, the registry created under the CEAA could be used for distribution of all documents. ${ }^{150}$ The use of the

Unless the project is referred to mediation or a Panel; then responsibility shifts to the Agency from the time of the appointment of the mediator or Panel until the report is submitted to the Minister. CEAA, ibid., s. 55(2).

Ibid., s. 55.

lbid., s. 55(4)(b).

148 Defined by s. 55(7) of the CEAA, ibid., as trade secrets of a third party; financial, commercial scientific or technical information that is confidential; information whose disclosure could reasonably be expected to result in material financial loss or gain, or lead to loss of competitive position for a third party; or information whose disclosure could reasonably be expected to interfere with contractual or other negotiations of a third party. Supra note 41.

In fact, s. 149(1)(e) of the Federal Accord Implementation Act, supra note 1, and s. 145(1)(e) of the Newfoundiand Accord Implementation Act, supra note 1, allow the Governor in Council to make regulations regarding approvals to be granted under s. 138(1)(b) and the power to incorporate, by reference, "the standards or specifications of any government, person or organization, either as of a fixed time or as amended from time to time" Federal Accord Implementation Act, ibid., s. 149(2) 
$C E A A$ registry as a common registry for all documents is encouraged by the proposed amendments under Bill C-19.

\section{Conclusions}

As set out above, the certainty created by the integration of these two regulatory approval regimes is of great benefit to the Proponent and the public, making the Newfoundland offshore more attractive and encouraging development while maximizing benefits to the people of the province. As long as the same factors are addressed, there are no procedural obstacles, the timelines coincide, and the role of the public is not diminished, there is no reason for any of the parties involved to deny the project owner that benefit of certainty.

If the two systems are merged, the Proponent's EIS and SEIS may be used as the basis for the comprehensive study, which avoids duplication, and/or the CNOPB hearing process can be substituted for the Panel under the $C E A A$, which provides a definite timeframe for the approval. In both of these examples, the rights of the public and the requirements of the two processes will not be reduced, and the Proponent will benefit.

This merger of the regulatory approval processes can occur, and should occur, so that the legislative goal of co-operation can be realized. 